\title{
The Impact of Student-Centered Instruction on EFL Learners' Affect and Achievement
}

\author{
Hassan M. Kassem ${ }^{1}$ \\ ${ }^{1}$ Tanta University, Egypt \& Shaqra University, Saudi Arabia \\ Correspondence: Hassan M. Kassem, Tanta University, Egypt \& Shaqra University, Saudi Arabia.
}

Received: November 6, 2018

Accepted: December 11, 2018 Online Published: December 15, 2018

doi: $10.5539 /$ elt.v12n1p134

URL: https://doi.org/10.5539/elt.v12n1p134

\begin{abstract}
This study explored the relative effect of student- and teacher-centered instruction on EFL freshmen's affect (anxiety, motivation, attitude, autonomy, self-efficacy and beliefs about English and its learning) and achievement. Two classes of English department freshmen at Shaqra University, KSA participated in the study. Students in the two classes completed a questionnaire probing the target affective variables. An independent t-test proved that the two classes were homogenous in affective variables before the treatment. The treatment class was taught according to student-centered instruction for an academic year. The control class was taught the same courses according to the conventional teacher-centered instruction. The students completed the questionnaire probing their affect. A composite mark of final exam marks of three courses was used as an index of achievement. Analyses of independent sample t-test proved that the treatment class outperformed the control class in all affective variables (except for instrumental motivation) and achievement.
\end{abstract}

Keywords: student-centered instruction, teacher-centered instruction, affective variables, anxiety, motivation, attitude, autonomy, self-efficacy, beliefs about language learning, achievement, EFL students

\section{Introduction}

Saudi EFL learners have been reported to have poor achievement (e.g., Al-Khairy, 2013; Alrahaili, 2013; Alrashidi \& Phan, 2015) and poor affect, namely, high anxiety (e.g., Al-Saraj, 2014; Mohammed, 2015), poor motivation (e.g., Al-Johani, 2009; Fareh, 2010; Alrabai, 2014), poor autonomy (e.g., Alrabai, 2016, 2017), low self-efficacy (e.g., Alrabai, 2014; Al-maqtri, 2016), and debilitative beliefs about English and its learning (Kassem, 2013). At the top of the sources to which researchers attributed poor achievement and poor affect among Saudi learners comes teacher-centered instruction that researchers documented as the dominant teaching approach in EFL classrooms in Saudi Arabia in all study levels. For instance, Alrabai (2016: 30) concluded from his data that poor language learning outcomes in Saudi Arabia are mainly caused by the prevalence of "teacher-centered approaches and spoon-feeding methods".

Teacher-centered instruction is now admitted to lead to poor language performance. It is said to prevent students' educational growth (DuckWorth, 2009) because in teacher-centered classrooms teachers do most of the work and learners are always passive recipients of knowledge. This negative correlation between teacher-centered instruction and achievement was empirically documented (e.g., Geisli, 2009; Alrabai, 2016). This type of instruction was also found to lead to poor affect (e.g., Mermelstein, 2015; Amiri and Saberi, 2007). Accordingly, researchers have called for a shift from teacher- to student-centered instruction.

There is a general consensus that student-centered instruction leads to better language learning and better affect compared with teacher-centered instruction, because students have better performance when they are encouraged to think instead of doing the thinking for them. McCombs and Whistler (1997) suggest that learner-centeredness creates a learning environment that promotes the highest levels of motivation and achievement for all learners. Research proved such theoretical contentions. For instance, Geisli (2009) explored the effect of student-centered instruction on language performance. The student-centered group achieved better performance than the teacher-centered group. Amiri and Saberi (2017) investigated the relative impact of learner- and teacher-centered instruction on Iranian EFL learners' motivation (50 Iranian high school students). A significant impact on motivation was found for student-centered instruction. 


\section{Statement of the Problem}

The researcher of the present study has been teaching EFL courses to English majors at the College of Sciences and Humanities at Shaqra University, KSA for several years. Throughout these years, the researcher noticed that students initiate their study with limited proficiency and that their achievement remains unsatisfactory throughout years of study. Besides, students have shown many signs of poor affect, namely high anxiety, low motivation, poor autonomy, low self-efficacy and debilitative beliefs about English and its learning. The researcher identified some of such debilitative beliefs among students admitted to the same college a few years ago (Kassem, 2013). This seems to be the case of all Saudi students studying English as a FL (Al-Khairy, 2013; Mohammed, 2015; Alrabai, 2016; Al-maqtri, 2016).

The researcher speculated that teacher-centered instruction is the main cause of poor language achievement and poor affect among students (as has been reported by a large number of studies conducted on comparable students, e.g., Al-Johani, 2009; Khan, 2011; Rajab, 2013; Mohammed, 2015) and that a shift to student-centered instruction can lead to better achievement and enhanced affect among the students. Hence, the researcher, who heads the English Department at the college, groped colleagues' interest in active learning or student-centered instruction. He then had some discussions with two lecturers who expressed enthusiasm about shifting to student-centered instruction in their classrooms. Based on those discussions an agreement was reached to attempt student-instruction instruction with a class for one year as an experiment. Those two lecturers have taught the courses of reading, writing, listening, grammar and introduction to literature in the first two levels. So those were the courses where active learning elements were integrated (see the experiment section for more details). As planned, the performance and affect of students in that experimental class would be compared with a control class where teacher-centered instruction was used. More specifically, the study addressed the following questions:

1) What is the effect of student-centered instruction on EFL freshmen's affective variables, namely anxiety, motivation, attitude, autonomy, self-efficacy and beliefs about language learning?

2) What is the effect of student-centered instruction on EFL freshmen's achievement?

\section{Review of Literature}

\subsection{Anxiety}

Researchers have speculated that the kind of anxiety experienced in the language classroom is state rather than trait anxiety. Arguing the distinctive nature of language anxiety, Horwitz, Horwitz and Cope (1986: 128) view FL anxiety as "a distinct complex of self-perceptions, beliefs, feelings, or behaviors arising from the uniqueness of the language learning process". Language anxiety is not specific to a particular language skill, even though speaking has been reported to be associated with the highest level of anxiety (Horwitz, Horwitz and Cope, 1986; Young, 1991). Listening (Elkhafaifi, 2005), reading (Sellers, 2000) and writing (Masny \& Foxall, 1992) have all been reported to be anxiety provoking to FL learners. It has been asserted that anxiety and poor language learning are correlated. Reflecting on anxiety as a cause of poor language performance, MacIntyre (1995: 96) suggests that "language learning is a cognitive activity that relies on encoding, storage, and retrieval processes, and anxiety can interfere with each of these by creating a divided attention scenario for anxious students". Similarly, Oxford (1999: 60) contends that anxiety damages language learners' achievement "indirectly through worry and self-doubt and directly by reducing participation and creating overt avoidance of the language".

Anxiety has affective, cognitive and behavioral components. The affective component includes the feelings of apprehension, uneasiness and fear. The cognitive component is reflected in such effects as apprehension of failure and decreased cognitive processing ability. Inhibited actions and attempts to escape the anxiety-provoking situation are among the behavioral reactions to anxiety (MacIntyre, 1995: 91). As to causes of FL anxiety, Horwitz, Horwitz, and Cope (1986) identified three sources of language anxiety: communication apprehension, test anxiety, and fear of negative evaluation. Communication in the FL, according to Horwitz, Horwitz, and Cope (1986) and MacIntyre (1995) can challenge the learner's self-concept as a competent communicator because of the limited proficiency in the FL relative to L1. Anxious FL learners feel less competent than their peers and are afraid of being negatively evaluated and of making mistakes (MacIntyre \& Gardner, 1989; Horwitz, 2001). They therefore abstain from participating in classroom activities, especially oral communication activities not to reveal themselves. Young (1991) identified six potential sources of language anxiety which include among them the three sources identified by Horwitz, Horwitz, and Cope (1986). These are personal and interpersonal anxieties (e.g., self-esteem and communication apprehension), learner beliefs about language learning, instructor beliefs about language teaching, instructor-learner interactions (e.g., teacher's harsh manner of correcting student mistakes), classroom procedures (e.g., speaking in front of class), and testing. 
Several researchers reported high anxiety levels among Saudi EFL learners (e.g., Alrabai, 2015; Al-Saraj, 2014; Mohammed, 2015). For instance, Mohammed (2015) explored EFL anxiety among 75 Saudi students randomly selected from Community College and Faculty of Education, Shaqra University. Students were found to be highly anxious. Such high levels of anxiety were reported to be the most significant reason for the low English competence of Saudi learners. As to causes of anxiety among Saudi EFL students, researchers reported fear of negative evaluation, communication apprehension, language tests, and teacher characteristics and practices (e.g., Alrabai, 2014a; 2015; Al-Saraj, 2014). Of teacher characteristics and practices that increase the debilitative affective filter for Saudi learners, Alrabai (2014a) identified lack of teacher support, unsympathetic teachers, negative student performance evaluations, teachers' lack of time for personal attention, threatening questioning styles, intolerance of learner errors, harsh correction or overcorrection of students' mistakes, assessment procedures that depend primarily on written tests, and the students' sense of being judged by the teacher or wanting to impress the teacher.

\subsection{Motivation}

Motivation is defined by Gardner (1985) as "the combination of effort plus desire to achieve the goal of learning the language plus favorable attitudes toward learning the language". According to Peacock (1997), it refers to interest in and enthusiasm for learning materials, persistence with the learning task, and levels of concentration and enjoyment. Thus defined, motivation is a prerequisite for successful FL learning because, in Dörnyei's (2005: 65 ) words, it "provides the primary impetus to initiate FL learning and later the driving force to sustain language and often tedious learning process". Reece and Walker (1997) suggest that a less able student who is highly motivated can achieve greater success than the more intelligent student who lacks motivation. The significance of motivation stems from the fact that it can prevail over difficulties (which are numerous in FL learning) that would undermine or halt progress (Oxford \& Shearin, 1994; Dörnyei, 1998). Research revealed that of all affective factors, motivation is the most determining factor of success in FL learning. In a study by Alrabai and Moskovsky (2016), five affective factors (motivation, attitudes, anxiety, self-esteem and autonomy) together accounted for between $85 \%$ and $91 \%$ of variance in achievement in a sample of Saudi university students, whereas motivation alone accounted for between $60 \%$ and $67 \%$ of that variance. In other words, each of the five variables was found to make a unique contribution to language performance but motivation emerged as the strongest predictor of achievement.

Gardner and Lambert (1972) identified two types of motivation: integrative and instrumental. Integrative motivation "describes learners who wish to integrate themselves into the culture of the second language group and become involved in social interchange in that group", whereas instrumental motivation refers to "acquiring the language as a means for attaining instrumental goals; furthering a career, reading technical material, translation and so forth" (Kroll \& De Groot, 2005: 170). Deci and Ryan (1985) offered another dichotomy of motivation. They classified motivation into intrinsic and extrinsic with intrinsic motivation referring to "motivation to engage in an activity for its own sake" and extrinsic motivation referring to "motivation to engage in an activity as a means to an end" (Pintrich \& Schunk, 2002: 245). Students who perceive learning as a goal in itself and find learning interesting and challenging are intrinsically motivated. Those who engage in learning for external factors such as earning a reward or avoiding punishment are extrinsically motivated (Dörnyei, 2001; Ehrman, Leaver, \& Oxford, 2003; Slavin, 2003).

Until recently integrative motivation was claimed to be a better predictor of effective learning than instrumental motivation (Gardner, 1980; Gass \& Selinker, 2001), because if learners are inherently interested in the target language and its culture they will read literature and exert more efforts to practice the language (Cook, 2001). However, there is no sufficient research base for this claim. On the contrary, there is some research evidence against this claim. For instance, Wong (2011) explored which type of motivation played a more important role among third-year Chinese ESL undergraduates. Instrumental motivation was found to be more important for those students.

The controversy about which type of motivation is more important led scholars to take into consideration the context where language learning takes place. For instance, Dörnyei (1990: 48) states that "The nature and effect of certain motivation components might vary as a function of the environment in which the learning takes place". Even Gardner who initially stressed the superiority of integrative motivation over instrumental motivation reviewed his theory and later (1988) stressed the variable and dynamic nature of motivation in language learning in different settings. For this reason, Gardner and MacIntyre (1992) added context to their conceptualization of motivation. This means that instrumental motivation may work better for given groups of learners than integrative motivation (Dörnyei, 1994), especially for those who have had limited access to the L2 culture (Oxford, 1996). That instrumental motivation is the prevailing orientation in FL settings has been supported by 
research, e.g., Saudi Arabia (Moskovsky, Christo, Alrabai, \& Fakieh, 2009), Spain (Bobkina \& Fernandez, 2012), Jordan (Tahaineh \& Daana, 2013) and Turkey (Goktepe, 2014). Al-Amr (1998) attributes why instrumental motivation is much more relevant in the Saudi setting than integrative motivation to the fact that English is being learned away from the target language speakers and their culture.

Several studies reported lack of motivation among Saudi EFL learners (Al-Johani, 2009; Fareh, 2010; Khan, 2011; Al-Khairy, 2013; Alrabai, 2014). Al-Johani (2009) and Khan (2011) asserted that EFL learners in Saudi Arabia lack motivation, which interferes with their progress in developing English proficiency. Alrabai (2011 \& 2014b) attributed lack of motivation among Saudi learners to a number of factors that included, among others, inappropriate teacher behaviors, students' low self-esteem and self-confidence, high language anxiety, low autonomy, and inappropriate methods of teaching. Al-Khairy (2013) also reported low motivation among Saudi students and mentioned many reasons for this among which is inappropriate teaching.

\subsection{Attitude}

Attitude is one of the affective factors that influence language learning (Visser, 2008). It is defined as "an individual's disposition to respond favorably or unfavorably to an object, person, institution, or event" (Ajzen, 1989: 241). Second or foreign language attitudes include attitudes towards the target language, its community, its culture, the social values associated with target language competence, as well as evaluations of other attitudinal objects, such as teachers, curriculum, and teachings methods (Gardner, 2001). According to Gardner (1985) attitude is an evaluative reaction inferred on the basis of the individual's beliefs or opinions about the referent. Wenden (1991) identified three interrelated components of attitude, namely cognitive, affective and behavioral. The cognitive component involves beliefs, thoughts or viewpoints about the referent. The affective component refers to the individual's feelings and emotions towards the referent. The behavioral component involves the tendency to adopt particular learning behaviors

Positive attitudes facilitate language learning (DeBot, Lowie, \& Verspoor, 2005). The role that attitude plays in SL/FL learning has been researched quite extensively (e.g., Dörnyei, 2005; Gardner, 2001, 2010; Yashima, 2002), and there is a general consensus that attitudes influence language learning. Brown (2000: 181) surveyed several studies about the effects of attitude on language learning and concluded that "positive attitudes towards the self, the native language group, and the target language group enhanced proficiency". Empirically, several studies reported a strong correlation between positive attitudes to the target language and its speakers and to the learning situation on one hand and language learning achievement on the other (e.g., Alrahaili, 2013; Gardner, 2001, 2010; Al-Tamimi \& Shuib, 2009). Conversely, negative attitudes were found to correlate with poor performance (Kiptui \& Mbugua, 2009).

Research reported inconsistent results concerning attitudes held by Saudi learners towards EFL. Al-Zahrani (2008) reported negative attitudes among Saudi secondary school male students. The researcher attributed negative attitudes to instructional and traditional techniques used by teachers. Alrahaili (2013) found that Saudi students (510 male and female university students) held generally positive attitudes towards English and its speakers, but not towards the target language group's social and religious values. Experimenting with 112 Saudi English major students from Umm Al-Qura University, Al-Samadani and Ibnian (2015) found overall positive attitudes towards English.

\subsection{Autonomy}

The most quoted definition of learner autonomy is Holec's (1981: 3), “...the ability to take charge of one's own learning". According to Littlewood (1996: 97), autonomy refers to "learners' ability and willingness to make choices independently", suggesting that "ability depends on possessing both knowledge about the alternatives from which choice have to be made and necessary skills for carrying out whatever choices seem most appropriate. Willingness depends on having both the motivation and confidence to take responsibility for the choices required". Knowledge and skills need to be learnt. Motivation and confidence require a supportive learning environment. Sinclair (2000: 5) pointed out some characteristics of learner autonomy that FL teachers need to know to get a better understanding of autonomy. First, autonomy is not innate, which means that it is teachable. Second, there are degrees of autonomy, which means that with appropriate practices autonomy can develop over time. In this respect, Nunan (1997: 201) contends that "fully autonomous learners are a rarity". Third, autonomy can be practiced both inside and outside the classroom. Fourth, autonomy has both social and individual dimensions, i.e., autonomy does not mean learning without other people. In this respect, Oxford (1990: 144-146) asserts that knowing how to make use of other people as interlocutors and sources of input is an indication of learner autonomy. Little (1991: 3-4) mentioned some misconceptions that are often associated to autonomous language learning. One misconception is that autonomy would mean learning without a teacher and 
that the teacher would have to give up all initiative and control. This is not true because it is the teacher who fosters autonomy among learners by teaching them the skills required for autonomous learning. Another misconception is that autonomy is something that teachers can do for their students (i.e., a teaching method). Autonomy is not a teaching method but rather a way of approaching learning (Benson, 2011: 2). It is a kind of culture that needs to be spread over time.

Benson (2001: 1) asserts that helping FL students become more autonomous has become one of the most prominent themes in the field of SL/FL teaching and learning. He accounts for this prominence by asserting that the person who knows how to learn learns efficiently. Little (2003) argues that learner autonomy is critical for several reasons. First, students who actively participate in their learning will most likely be more efficient and more effective. Second, active engagement in learning enhances learners' motivation, so they can persist in the face of difficulties which are numerous in FL learning. Third, learning a language requires independent efforts on the part of learners in order to use the language in natural communication and ultimately develop their communicative competence. Research conducted in FL contexts reported a positive relationship between autonomy and students' language proficiency. Dafei (2007) found a correlation between autonomy and students' language proficiency among a sample of 129 non-English majors in a teacher college in China. This same finding was reported for 721 Japanese university students from 16 universities (Saka \& Takagi, 2009). Afshar, Rahimi and Rahimi (2014) studied relationships between instrumental motivation, critical thinking, autonomy and academic achievement of Iranian EFL learners (100 Iranian learners majoring in English language). Autonomy correlated significantly highly with academic achievement, followed by instrumental motivation and critical thinking.

For the FL classroom to be learner autonomy supportive, there should be, as recommended by Little (2009: 224), three principles: learner involvement, learner reflection and target language use. Strategy training is also recommended, as it furnishes learners with the skills they need to be autonomous in their approach to learning (Benson, 2001). What is required also is a shift in the teacher's and the learner's roles in the classroom. The role of the teacher needs to change from an authoritative conveyor of knowledge into a facilitator and a guide of the learning process. By the same token, learners' role needs to change from passive recipients of knowledge into active planners of their own learning. They should have a say in all aspects of their learning. The development of learner autonomy is "a move from teacher-directed teaching environment to a learner-directed learning environment" Dam (2011: 41). In order for learners to shift to the new role, there is a need to overcome an obstacle that has an aversive impact on the development of learner autonomy. That is the resistance of "teacher-centered students" (Lewis \& Reinders, 2008: 97) who might see no value in non-language activities related to autonomous learning such as reflection on and evaluation of progress.

In the Saudi context, there is no concern for learner autonomy to the extent that it was described as anti-autonomy by Alrabai (2016: 30). This judgment was based on survey studies he conducted in several Saudi schools. He wrote "Promoting readiness for spontaneous, self-directed, lifelong learning and enhancing such metacognitive skills as self-assessment, recognition of one's strengths and weaknesses, and planning and implementing suitable strategies -all of which are important features of learner autonomy- are not incorporated into EFL education in Saudi Arabia". He attributed absence of autonomy in Saudi classrooms to teacher-centered approaches and spoon-feeding methods of teaching. Empirically, Alrabai (2017) investigated the level of autonomy in a sample of 630 Saudi students and its relationship to academic achievement. Students were found to be non-autonomous, with a mean autonomy score of 2.35 out of 5 ; and also low language achievers $(\mathrm{M}=66$ out of 100).

\subsection{Self-Efficacy}

Bandura (1986: 391) defines self-efficacy as "people's judgments of their capabilities to organize and execute courses of action required to attain designated types of performances". Bandura (1997) attributes self-efficacy to four sources: mastery experience, vicarious experience, persuasions and psychological states. Mastery experience means that one's achievements raise their level of self-efficacy. Reflecting on this, Bandura (1997: 80) suggests that "successes rebuild a robust belief in one's personal efficacy" while "failures undermine it, especially if failures occur before a sense of efficacy is firmly established". Vicarious experience relates to other individuals' achievements that motivate us to believe that we have the same ability in gaining achievements. Persuasions means that what others say can influence our beliefs about our abilities. If Individuals are verbally encouraged and explained that they can perform a task, they are more likely to perform it well. Psychological states like anxiety, stress, and fear can influence our behavior. Bernhardt (1997) describes self-efficacious learners as learners who feel really confident because of the experiences they have gained in solving problems and the approaches they have developed based on those problem solving experiences. It is therefore argued that 
self-efficacy is a major predictor of student achievement in addition to knowledge, skill, value, and expectation (Schunk, 2003), for it determines learners' willingness to expend effort in the activity concerned (Wigfield \& Guthrie, 1997).

Self-efficacy contributes to successful learning. Language learners need to initiate learning tasks with the prospect that they will perform them successfully. It is the duty of teachers to identify learners with low self-efficacy and to encourage them to believe more in their capabilities. In this respect, Bandura (1986: 390) states that "many students have difficulty in school not because they are incapable of performing successfully, but because they are incapable of believing that they can perform successfully". Learners who have high self-efficacy go through demanding tasks regularly and have tendency to gain higher than students with low self-efficacy (Pajares, 1996). Self-efficacy beliefs regulate human functioning by determining "whether individuals think in self-enhancing or self-debilitating ways; how well they motivate themselves and persevere when they face any difficulties; the quality of their emotional life and vulnerability to stress" (Tilfarlioğlu \& Cg்nkara, (2009).

Research proved that self-efficacy is a significant predictor of learning and achievement (Chemers, Hu \& Garcia, 2001; Mills, Pajares, \& Herron, 2007; Rahemi, 2007; Rahimi \& Abedini, 2009; Tilfarlioğlu \& Cg̈nkara 2009; Li \& Wang 2010; Doordinejad \& Afshar, 2014). For instance, Chemers, Hu and Garcia (2001) found a positive relationship between academic self-efficacy and grade point averages among first-year college students at the University of California. Mills, Pajares and Herron (2007) found a significant relationship between reading self-efficacy and reading proficiency and between listening self-efficacy and listening proficiency. Tilfarlioğlu and Cgnkara (2009) investigated the relationship between self-efficacy and English achievement among third grade high school students in Northern Tehran. A moderately significant relationship was found between self-efficacy and English achievement.

\subsection{Beliefs}

Beliefs about language learning are described as subjective assumptions, representations and notions that learners hold to be true about language learning. They form a metacognitive framework with certain conceptions that learners hold about themselves, the nature and difficulty of language learning, the role of variables such as age, gender or aptitude on the learning process, and the usefulness of certain learning strategies (Öz, 2007; Richards \& Schmidt, 2002). According to Horwitz (1987: 121), beliefs refer to learners' ideas or opinions about various aspects of language learning, including "foreign language aptitude, the difficulty of language learning, the nature of language learning, the use of learning and communication strategies and the effect of motivation". Researchers identified several sources that shape learners' beliefs about language learning. These include family and home background (Dias, 2000), cultural background (Alexander \& Dochy, 1995), classroom/social peers (Arnold, 1999), and interpretations of prior repetitive experiences (Gaoyin \& Alvermann, 1995; Kern, 1995). Learners' beliefs, as asserted by Wenden (1999), can be both conscious and unconscious. They can be acquired unconsciously through observation and imitation, and consciously through listening to teachers, parents or even partners when giving advice about how to learn.

Young (1991) considers learner beliefs about language learning as a major contributor to language success, as they may be the basis of students' expectations for and commitment to successful language learning. Beliefs FL learners hold about language and language learning can be positive or negative. Positive or supportive beliefs help to overcome problems and thus sustain motivation, while negative or unrealistic beliefs can lead to decreased motivation, frustration and anxiety (Kern, 1995; Oh, 1996). An example of negative beliefs that learners may hold is beliefs about the difficulty of language learning. Learners who perceived the target language as difficult were found to have higher anxiety than those who believed they were learning an easy language (Horwitz, 1989; Truitt, 1995). Mori (1999) found that learners who perceived the target language as an easy language tended to do better than those who believed that they were dealing with a difficult language. In a study by Mantle-Bromley (1995: 382) learners with realistic or informed beliefs were more likely to behave productively and persist longer with study. Low and high proficient FL learners were found to possess different beliefs about language learning. For instance, Mori (1999), in her study of 187 American college students studying Japanese, found significant correlations between some beliefs and achievement. Bagherzadeh (2012) reported similar results. The more proficient participants (in a sample of 125 male and female Iranian non-English majors) were found to hold strong beliefs in the category of motivation and expectations.

Knowledge of such beliefs provides language educators with a better understanding of their learners' "expectation of, commitment to, success in and satisfaction with their language classes" (Horwitz, 1988: 283). Based on this knowledge, teachers can make more informed choices about teaching (Bernat \& Gvozdenko, 2005; 
Frugé, 2007) and adopt "a more sensitive approach to the organization of learning opportunities" (Cotterall, 1999: 494). Research revealed that Saudi EFL learners at various levels of language learning hold several debilitative beliefs (e.g., Kassem, 2013). These included, among others, the beliefs that mastering a foreign language requires a special ability, that learning a foreign language is a matter of memorizing vocabulary and grammatical rules, and that a learner should master the language before using in communication. Such beliefs need to be identified and modified in order to improve the learning of foreign languages.

\subsection{Student-Centered Instruction}

According to Richards and Schmidt (2010: 326), student-centered teaching is based on "a belief that attention to the nature of learners should be central to all aspects of language teaching, including planning teaching, and evaluation. Learning is dependent upon the nature and will of the learners". Student-centered instruction rests upon the assumptions of the constructivist view that places most emphasis on the construction of knowledge on the part of learners. Learners according to this view are not passive recipients of knowledge. Rather, they actively construct knowledge through gathering and synthesizing information and integrating this information with skills such as inquiry, communication, and critical and creative thinking (Huba \& Freed, 2000; Brown, 2008). Unlike teacher-centered approaches where most work is done by teachers, student-centered instruction is an instructional approach in which students influence the content, activities, materials, and pace of learning. The teacher is not a provider of knowledge, but a provider of opportunities from which learners can learn independently and from one another. The teacher also coaches learners in the skills they need for independent learning (Collins \& O’Brien, 2003: 399).

Related literature provides student-centered models where students are responsible for such big decisions as setting goals and selecting content. This is not viable in most FL settings for many considerations. Some researchers therefore recommend a gradual shift to student-centered classrooms to evade student and teacher resistance. To achieve this gradual shift, teachers are recommended to train students on learning strategies and create meaningful activities that encourage students to process information in different ways (Cooper, MacGregor, Smith, \& Robinson, 2000). Researchers (e.g., Lynch, 2010) also recommend that teachers use social activities like collaboration, meaningful communication and cooperation. Peyton, More and Young (2010) recommend certain elements as basic for active learning. These include promoting interaction among learners and teaching learning strategies explicitly.

There is a general consensus that student-centered instruction leads to better language learning and better affect compared with teacher-centered instruction. Students have better performance when they are encouraged to think instead of doing the thinking for them. Teacher-centered instruction is said to prevent students' educational growth (DuckWorth, 2009). McCombs and Whistler (1997) suggest that learner-centeredness creates a learning environment that promotes the highest levels of motivation and achievement for all learners. Research proved such theoretical contentions. Geisli (2009) explored the effect of student-centered instruction on language performance. The student-centered group achieved better performance than the teacher-centered group. Amiri and Saberi (2017) investigated the relative impact of learner- and teacher-centered instruction on Iranian EFL learners' motivation (50 Iranian high school students). A significant impact on motivation was found for student-centered instruction. Mermelstein (2015) groped the preferences of 225 Taiwanese EFL university students toward three main teaching approaches: instructor-centered, student-centered, and content-centered. Students recognized the differences among the teaching approaches, had a clear preference toward the student-centered approach, and held more positive attitudes toward student-centered learning.

According to several studies, only teacher-centered instruction is used in the Saudi context (e.g. Fareh, 2010; Alrabai, 2014; Al-maqtri, 2016). For instance, Alrabai (2014) found that teachers in the Saudi classrooms adopt the role of presenters of knowledge rather than facilitators of learning. As a result, Saudi students still rely on the teacher as the main source of knowledge. Fareh (2010) indicated that English teachers in the Saudi classrooms spend the majority of the lesson talking and rarely allow students a chance to speak or ask questions. Al-maqtri (2016) investigated the extent to which classroom instruction in Saudi departments of English is students-centered. Teachers surveyed were found to be unaware of the concept of student-centeredness and when they were aware of it, they gave contradictory responses about it. The researcher identified several constraints of applying student-centered instruction related to students, teachers, the system and the family. Examples of student-related constraints are that the majority of students are not motivated to learn English, that students are not willing to work in groups or teams, and that students are happy to be under the teacher control. Teacher-related constraints included such observations as lack of awareness of student-centered instruction and reluctance to change roles. 


\section{Method}

\subsection{Participants}

Two intact classes of English freshmen at Thadiq Sciences and Humanities College, Shaqra University, KSA participated in the present study. Students in the first year of the English program at Shaqra University study skill courses, namely Listening and Speaking 1 (Eng 112), Listening and Speaking 2 (Eng 122), Reading Comprehension 1 (Eng 113), Reading Comprehension 2 (Eng 115), Vocabulary (Eng 120), Paragraph Writing (Eng 114), and Introduction to Literature (Eng 118). All the participants were male students (for there is segregation in Saudi universities). Their average age was 18 years. They had the same language experience in terms of years of study and rate of exposure to the language. One class served as the experimental group $(\mathrm{N}=47)$ and the other was the control group $(\mathrm{N}=39)$. The experimental group was taught according to the student-centered approach, whereas the control group was taught according to the conventional teacher-centered approach.

\subsection{The Questionnaire}

The researcher reviewed related literature to develop the questionnaire probing students' anxiety (Horwitz, Horwitz \& Cope, 1986), motivation (Gardner \& Lambert, 1972; Vallerand, Pelletier, Blais, Briere, Senecal, \& Vallieres, 1992; Schmidt, Boraie, \& Kassabgy, 1996; Noels, Pelletier, Clément, \& Vallerand, 2000), attitude (Gardner, 1985; Boonrangsri, Chuaymankhong, Rermyindee, \& Vongchittpinyo, 2004), autonomy (Cotterall, 1995, 1999), self-efficacy (Henk \& Melnick, 1995; Seeger, 2009), and beliefs about English and its learning (Horwitz, 1987). The questionnaire that initially included 120 items was content validated by three EFL professors to decide on its validity for probing EFL students' affect. Based on recommendations, several items were either reworded or deleted. This left the questionnaire with 87 items assessing the six affective variables: anxiety (12 items), motivation (10 items), attitude (14 items), autonomy (22 items), self-efficacy (20 items), and beliefs (9 items). The questionnaire was then piloted on 30 students rather than those who participated in the main experiment to check its internal consistency. The summated rating method was used in scoring the questionnaire. Participants were asked to respond to items by indicating how far they agreed to the statements on a five-point rating scale. Each response was associated with a point value, where "Strongly agree" was assigned a point value of 5 and the response "Strongly disagree" a point value of 1 . Items with negative statement were reverse coded so that higher scores indicated higher anxiety, motivation, attitude, autonomy, self-efficacy and beliefs. Alpha estimates of internal consistency for the individual variables and the whole questionnaire were quite reliable (anxiety .95, motivation .75, attitude .77 , autonomy .87 , self-efficacy .85 , beliefs .77 , and total questionnaire .89).

\subsection{Pretesting}

To avoid the risk that limited English competence would compromise participants' capacity to respond to the questionnaire items, the questionnaire was administered in Arabic. Furthermore, it was administered to participants in two sessions so that fatigue and boredom would not affect results. Participants were told that their scores on the questionnaire would be used only for research purposes. In order to make sure the two groups were homogeneous prior to the experiment, an independent-samples t-test was performed to compare the questionnaire mean scores of the two groups. The resulting t-values indicated that the two groups were homogeneous before the experiment in the affective variables. That is, the two groups were homogenous before the experiment. The following table shows the data of this statistics.

Table 1. Means, standard deviations and t-values for mean differences between the two groups on pretest scores of affective variables

\begin{tabular}{lllllll}
\hline & Group & $\mathrm{N}$ & $\mathrm{M}$ & $\mathrm{SD}$ & t-value & Sig. \\
\hline \multirow{2}{*}{ Anxiety } & T-C & 39 & 3.16 & .225 & -.720 & .479 \\
& S-C & 47 & 3.23 & .238 & & \\
Instrumental Motivation & T-C & 39 & 3.28 & .353 & .298 & .776 \\
& S-C & 47 & 3.19 & .442 & & \\
Integrative Motivation & T-C & 39 & 3.41 & .174 & \multirow{2}{*}{-1.18} & .263
\end{tabular}




\begin{tabular}{lllllll}
\multirow{2}{*}{ Attitude } & T-C & 39 & 3.58 & .252 & -1.04 & .304 \\
\multirow{3}{*}{ Autonomy } & S-C & 47 & 3.68 & .245 & & \\
\multirow{3}{*}{ Self-efficacy } & T-C & 39 & 3.47 & .302 & -1.21 & .235 \\
\multirow{3}{*}{ Beliefs } & S-C & 47 & 3.36 & .342 & & \\
& T-C & 39 & 3.27 & .444 & -1.01 & .318 \\
\hline
\end{tabular}

\subsection{The Treatment}

The treatment lasted for an academic year (2017/2018), i.e., two semesters. The control class was taught according to the conventional type of teaching which is teacher-centered. The experimental class was taught according to SCI. The researcher and the two lecturers who would teach the experimental class agreed upon the active learning elements that would be integrated in different courses several months before the initiation of the treatment, so the lecturers would read about the target elements and observe models of them on the Internet. The general elements of active learning that were agreed upon included allowing students to (1) select supplementary material and resources, (2) participate in setting goals for learning in different courses, (3) use language learning strategies, (4) use the internet and the library for further practice or in search for information, and (5) keep a portfolio for every course where they reflected on their learning and the progress they have achieved (in English, Arabic or both). The lecturer collected portfolios periodically, examined them and talked to students about issues of concern. Sometimes he talked to the whole class and other times to students individually depending on whether what he wanted to comment on related to individual students' concerns or general issues that related to all students). What follows are the active learning elements in relation to the study courses ( 8 courses).

Reading Comprehension (Eng $113 \& 115$ ): Students were allowed to identify topics for further reading and to identify aims for reading. They used collaborative and individual strategic reading. For this purpose, the lecturer taught them how to use strategic reading through the steps of direct explanation and modeling, guided practice and independent use. Students were divided into groups and assigned the roles of leader, clunk expert, gist expert, announcer and encourager. According to strategic collaborative reading and through the specified roles students in their groups brainstormed and predicted ideas, applied fix-up strategies whenever coming at difficult items, summarized paragraphs in their own words, generated questions on the passage, and answered questions on the passage. They used strategic reading individually in class by producing concept maps, monitoring their comprehension as they read passages, and answering post-reading comprehension questions. They used strategic reading with passages of their choice at home and kept the passages they read with the concept maps they produced and instances of comprehension breakdowns that they had overcome with fix-up strategies in the Reading Portfolio. They were also asked to include Internet sites or library references they used to get passages or to do more training on specific aspects of reading. Finally they were encouraged to reflect on their progress in reading in their portfolios.

Paragraph Writing (Eng 114): Students were allowed to identify topics of their choice for further practice in paragraph writing. They used writing strategies in groups and individually. The strategies they were initially trained on and later used collaboratively and individually included producing concept maps, converting propositions in the maps to sentences, using linking words and conjunctions to make writing coherent and cohesive, and editing compositions. They were encouraged to use Internet sites for writing activities. They were also encouraged to include compositions they wrote at home and to write about their progress in the Writing Portfolio.

Listening and Speaking (Eng 112 \& 122): Students used listening strategies after they were trained on how to use them. These included metacognitive (e.g., using the setting and the relationship between speakers to guess the meaning of unknown words, reflecting on the listening task with classmates after the listening task is over, recovering concentration whenever it is lost), cognitive (e.g., picturing the setting of the conversation to understand what the speakers are talking about, making predictions about the listening material based on the title, making a mental summary of the listening material) and socioaffective (e.g., self-encouragement, talking to the teacher and classmates about how to be a better listener of English). As to speaking they were trained on communication and compensation strategies to be able to express themselves when they run short of lexical 
items. They did several speaking activities that allow for freedom of expression and negotiation of meaning (e.g., role-plays, debates, panel discussions). Such activities were led by the lecturer for a few times and later by the students themselves. The students were told to use Internet sites for more practice with listening and to include those sites and their reflections on the experiences in the Listening portfolio.

Vocabulary (Eng 120): Students used vocabulary learning strategies both in groups and individually after they were trained on them. These included strategies like guessing words from the context, identifying the meaning of words by analyzing them structurally, and using newly learned vocabulary in sentences. They kept vocabulary notebooks where they wrote the new words they have learned in the different courses along with sentences, pictures and other illustrations. They also included the Internet sites they used for more practice with vocabulary.

Grammar (Eng 111): students learned grammatical rules both deductively and inductively based on the nature of the rules. They worked in groups to produce examples of the target rules. They used internet sites for more practice and for testing their grasp of the target rules. They kept a grammar notebook where they wrote the rules they learned with examples and their reflections on the Internet activities and their performance as indicated by the scores they got in assessment sections on the sites.

Introduction to Literature (Eng 118): The aim of this course is to teach students the main literary terms that they will be exposed to in their future study of the various literary genres, i.e., poetry, drama and novel. The lecturer explained the terms with examples and got them, in groups, to give examples from their native literature. They were also asked to refer to the library or the Internet for further examples. In public they stated the examples they obtained from the Internet when they came to class. As usual they kept a literary notebook where they wrote the literary terms with their examples. They also wrote in their notebooks about the difficulties they met and how they overcame them using the different learning resources.

The researcher visited the experimental class several times to observe how the active learning elements were being implemented. The lecturers were found to adhere to the planned elements of SCI. The students were enthusiastic during the various learning activities. The researcher also read a sample of the student's portfolios for the different courses to make sure they were actively working on their learning. The students even did some speaking activities in public in the theatre where staff members and other students attended. Such procedures revealed a sufficient degree of implementation fidelity.

\subsection{Posttesting}

The questionnaire was administered to participants in two sessions. Composite scores of students' final grades in three courses (Reading Comprehension 2, Paragraph wring \& Listening and Speaking 2) were used to compare between the two classes in achievement. The independent-samples t-test was used to explore the differences between the two classes in the affective variables and achievement after the treatment.

\section{Results}

\subsection{Effects of Student-Centered Instruction on Affective Variables}

Significant differences were found between the two classes on all the affective variables except for instrumental motivation in favor of the treatment class. More specifically, the treatment class outperformed the control class in anxiety $(\mathrm{t}=4.24, \mathrm{p}=.000)$, integrative motivation $(\mathrm{t}=4.79, \mathrm{p}=.001)$, attitude $(\mathrm{t}=5.73, \mathrm{p}=.000)$, autonomy $(\mathrm{t}=3.61, \mathrm{p}=.001)$, self-efficacy $(\mathrm{t}=2.74, \mathrm{p}=.009)$, and beliefs $(\mathrm{t}=3.18, \mathrm{p}=.006)$. This indicates that SCI leads to better affect than teacher-centered instruction. These results are summarized in Table 2 below.

Table 2. Means, standard deviations and t-values for mean differences between the two classes on posttest scores of affective variables

\begin{tabular}{|c|c|c|c|c|c|c|}
\hline & Group & $\mathrm{N}$ & $\mathrm{M}$ & SD & t-value & Sig. \\
\hline \multirow{2}{*}{ Anxiety } & T-C & 47 & 3.16 & .230 & \multirow{2}{*}{4.24} & \multirow{2}{*}{.000} \\
\hline & $\mathrm{S}-\mathrm{C}$ & 39 & 2.64 & .356 & & \\
\hline \multirow{2}{*}{ Instrumental Motivation } & $\mathrm{T}-\mathrm{C}$ & 47 & 3.35 & .421 & \multirow{2}{*}{-1.39} & \multirow{2}{*}{.213} \\
\hline & $\mathrm{S}-\mathrm{C}$ & 39 & 3.94 & .738 & & \\
\hline \multirow{2}{*}{ Integrative Motivation } & $\mathrm{T}-\mathrm{C}$ & 47 & 3.38 & .216 & \multirow{2}{*}{-4.79} & \multirow{2}{*}{.001} \\
\hline & S-C & 39 & 4.30 & .420 & & \\
\hline
\end{tabular}




\begin{tabular}{lcccccc} 
Attitude & T-C & 47 & 3.63 & .176 & -5.73 & $\mathbf{. 0 0 0}$ \\
\multirow{3}{*}{ Autonomy } & S-C & 39 & 4.30 & .402 & & \\
\multirow{3}{*}{ Self-efficacy } & T-C & 47 & 3.33 & .362 & & \\
& S-C & 39 & 3.76 & .410 & -3.61 & $\mathbf{. 0 0 1}$ \\
Beliefs & T-C & 47 & 3.25 & .478 & & \\
& S-C & 39 & 3.63 & .403 & -2.74 & $\mathbf{. 0 0 9}$ \\
\hline
\end{tabular}

\subsection{Effects of Student-Centered Instruction on Achievement}

A significant difference was found between the two classes in achievement in favor of the treatment class $(\mathrm{t}=$ $4.18, \mathrm{p}=.000$ ). This indicates that SCI leads to better achievement than TCI. Table 3 below presents these data.

Table 3. Means, standard deviations and t-values for mean differences between the two groups in achievement

\begin{tabular}{lllllll}
\hline & Group & N & M & SD & t-value & Sig. \\
\hline \multirow{2}{*}{ Achievement } & T-C & 47 & 206.00 & 11.00 & -4.181 & \multirow{2}{*000}{} \\
& S-C & 39 & 216.20 & 11.56 & & \\
\hline
\end{tabular}

\section{Discussion}

Based on the findings of the present study, SCI proved to be more effective than TCI in promoting EFL students' affect. It enhanced students' integrative motivation, attitudes towards the language, self-efficacy, autonomy and beliefs about language learning. It also reduced students' anxiety. It increased instrumental motivation but that increase did not reach the significance level. This finding concurs with pervious research (e.g., Mermelstein, 2015; Amiri \& Saberi, 2017). It seems logical that students who take charge of their learning develop stronger motivation, better attitudes, higher levels of self-efficacy and autonomy, and more facilitative beliefs about the language and its learning than students who are totally dependent on their teachers. Students with debilitative anxiety can gradually get rid of their anxiety and become more self-efficacious when they actively participate in different formats of learning activities, i.e., in pairs, small groups and individually. Students who experience success in learning activities reduce their anxiety and develop stronger self-efficacious beliefs in their capabilities. In this respect, Bandura (1997: 80) suggests that "successes rebuild a robust belief in one's personal efficacy" and "failures undermine it, especially if failures occur before a sense of efficacy is firmly established".

Debilitative beliefs about language learning are often groundless misconceptions. Active learning practices can help learners have a better understanding of language learning. With appropriate learning activities, learners, for example, can find language learning a possible task that does not need special ability. SCI, as supported by McCombs and Whisler (1997) creates a learning environment conducive to learning and promotes the highest levels of affect for all learners. It is worth mentioning here that all affective variables are interrelated. A language learner who is highly motivated will have better attitudes towards the language, experience less anxiety when learning it, have stronger belief in own competence, take more ownership of own learning, and develop more favorable beliefs about the language and its learning. This holds true if the statement begins with a language learner who is self-efficacious, etc. The researcher through the visits he paid to the treatment classroom noticed that the students were enthusiastic and seemed to enjoy what they were doing. Their growing interest was also expressed in their portfolios. The lecturers also conveyed the same impression about the favorable affect of students. Such favorable affect seems to be lacking in TCI as I have always noticed in classrooms taught according to TCI and as reported by Bahous, Bacha \& Nabhan (2011) who investigated the affect of Lebanese University EFL students. The researchers found that students were not motivated to learn English and therefore recommended that teachers shift to practices of SCI so students would develop better affect.

SCI was also found to lead to better language learning in comparison with TCI. This improvement can be due to students' active participation in the various learning activities that were incorporated in the treatment. Individuals who take ownership of their learning tend to be more focused and more purposeful, and are as a result more 
effective and more successful learners (Little, 1991: 8). The improvement can also be due to the improved affect that might have resulted in students' exerting more enthusiastic efforts in their learning. According to some scholars better affect leads to better language learning and in reverse better language learning leads to better affect. Reece and Walker (1997) suggest that a less able student who is highly motivated can achieve greater success than the more intelligent student who lacks motivation. That better affect leads to better language learning seems to be uncontroversial. In this respect, Schumann (1998) states "I believe that emotion underlies most if not all cognition and I will argue that variable success in second language acquisition (SLA) is emotionally driven". This underlies the great emphasis that researchers place on affective variables. Arnold and Brown (1999: 2) stress the significant role that affective variables play in language learning. They suggest that "When dealing with the affective side of language learners, attention needs to be given both to how we can overcome problems created by negative emotions and to how we can create and use more positive, facilitative emotions."

The current study's finding concerning the improvement in achievement is in line with previous research. SCI promoted 120 Iranian EFL students' reading comprehension (Lak, Soleimani, \& Parvaneh, 2017). It promoted EFL students' quality of learning (Atara, Wong, Woon, \& David, 2000; Gravoso \& Pasa 2008). In a study by Alrabai and Moskovsky (2016), five affective variables (motivation, attitudes, anxiety, self-esteem and autonomy) accounted for between $85 \%$ and $91 \%$ of variance in Saudi university EFL students' performance. Research also reported positive relationships between achievement and individual affective variables: attitudes (Gardner, 2001, 2010; Alrahaili, 2013), self-efficacy (Schunk \& Pajares, 2005; Rahemi, 2007; Doordinejad \& Afshar, 2014) and autonomy (Alrabai, 2017). Anxiety was reported to correlate negatively with EFL students' achievement (Alshahrani, 2016). That is, reduction of anxiety can improve students' achievement because students with normal anxiety will not abstain from participating in learning activities.

\section{Conclusion and Implications}

SCI enhanced EFL students' affective variables and achievement in comparison with TCI. FL Teachers are therefore recommended to shift their instruction to SCI and create a classroom environment that is conducive to learning. This shift does not need to be abrupt. It can be implemented gradually by adding the more viable elements of active learning first and add other less viable elements with time. SCI not only enhances achievement, but it also promotes affect. Promotion of students' affect is a dream for FL teachers who suffer from their students' having debilitative affect, e.g., amotivation, anxiety, lack of self-efficacy and negative beliefs about language learning. SCI should be incorporated in programs offered to prospective FL teachers. It is also recommended that in-service teachers be offered training courses to train them on how to apply active learning practices. Inclusion of SCI in pre-service and in-service programs is important to inculcate in teachers the culture of active learning. A core belief in such culture is that SCI does not relinquish teacher's initiative and control (Little, 1991: 3). The adoption of SCI has become a must in order to produce learners who are developers of knowledge, not only absorbers of it.

\section{References}

Afshar, S., Rahimi, A., \& Rahimi, M. (2014). Instrumental motivation, critical thinking, autonomy and academic achievement of Iranian EFL learners. Issues in Educational Research, 24(3), 281-298.

Ajzen, I. (1989). Attitudes, Personality, and Behaviour. Milton Keynes, England: Open University Press.

Al-Amr, B. (1998). Attitudes, motivation, and socio-cultural effects on English foreign language learning and proficiency: the Saudi Arabian context. MA thesis. Essex: University of Essex.

Alexander, P., \& Dochy, F. (1995). Conceptions of knowledge and beliefs: A comparison across varying cultural and educational communities. American Educational Research Journal, 32(2), 413-442.

Al-Johani, H. (2009). Finding a way forward the impact of teachers' strategies, beliefs and knowledge on teaching English as a foreign language in Saudi Arabia. Doctoral Dissertation. University of Strathclyde, Glasgow, Scotland, UK.

Al-Khairy, M. (2013). English as a foreign language learning demotivational factors as perceived by Saudi undergraduates. European Scientific Journal, 9, 365-382.

Al-maqtri M. (2016). Learner-centered Instruction in English Education: Reality and Expectations. Arab World English Journal, 7(1), 108-122.

Alrabai, F., \& Moskovsky, C. (2016). The Relationship between Learners' Affective Variables and Second Language Achievement. Arab World English Journal, 7(2), 77-103. 
Alrabai, F. (2011). Do motivational strategies work? An empirical investigation of the effectiveness of motivational strategies in foreign language classes. Saarbrücken, Germany: Lambert Academic Press.

Alrabai, F. (2014a). A Model of Foreign Language Anxiety in the Saudi EFL Context. English Language Teaching, 7(7), 82-101.

Alrabai, F. (2014b). Motivational practices in English as a foreign language classes in Saudi Arabia: Teachers beliefs and learners perceptions. Arab World English Journal, 5(1), 224-246

Alrabai, F. (2015). The influence of teachers' anxiety reducing strategies on learners' foreign language anxiety. Innovation in Language Learning and Teaching, 9(2), 163-190.

Alrabai, F. (2016). Factors Underlying Low Achievement of Saudi EFL Learners. International Journal of English Linguistics, 6(3), 21-37.

Alrabai, F. (2017). Exploring the Unknown: The Autonomy of Saudi EFL Learners. English Language Teaching, 10(5), 222-233.

Alrahaili, M. (2013). Predictors of L2 attitudes and motivational intensity: A cross-sectional study in the Saudi EFL context. Ph. D Thesis, the University of Newcastle, Callaghan, Australia.

Alrashidi, O., \& Phan, H. (2015). Education context and English Teaching and learning in the Kingdom of Saudi Arabia: An overview. English Language Teaching, 8(25), 33-44.

Al-Samadani, H. \& Ibnian, S. (2015). The Relationship between Saudi EFL Students' Attitudes towards Learning English and their Academic Achievement. International Journal of Education and Social Science, 2(1), 92-102.

Al-Saraj, T. (2014). Foreign language anxiety in female Arabs learning English: Case studies. Innovation in Language Learning and Teaching, 8(3), 257-278.

Alshahrani, M. (2016). The Effect of Anxiety on the Achievement of the Saudi EFL Learners. Arab World English Journal, 7(3), 65-76.

Al-Tamimi, A. \& Shuib, M. (2009). Motivation and attitudes towards learning English: A study of petroleum engineering undergraduates at Hadhramout University of Sciences \& Technology. GEMA Online Journal of Language Studies, 9(2), 29-55.

Al-Zahrani, M. (2008). Saudi secondary school male students' attitudes towards English: An exploratory study. King Saudi University, Language \& translation, 20, 25-39.

Amiri, F., \& Saberi, L. (2017). The impact of learner-centered approach on Learners' motivation in Iranian EFL students. International Academic Journal of Social Sciences, 4(1), 99-109.

Arnold, J., \& Brown, H. (1999). A map of the terrain. In J. Arnold (Ed.), Affect in Language Learning. UK: Cambridge University Press.

Atara, S., Wong, R., Woon, \& David, K. (2000). An Implementation of Active Learning and its Effect on the Quality of Student Learning. Innovations in Education and Teaching International, 37(4), 381-389.

Bagherzadeh, H. (2012). Learners' Beliefs about English Language Learning: Examining the Impact of English Proficiency Level on the Motivation of Students among Non-English Major EFL Students. Journal of Language Teaching and Research, 3(4), 784-792.

Bahous, R., Bacha, N., \& Nabhani, M. (2011). Motivating Students in the EFL Classroom: A Case Study of Perspectives. English Language Teaching, 4(3), 33-43.

Bandura, A. (1986). Social foundations of thought and action: A social cognitive theory. Englewood Cliffs, NJ: Prentice Hall.

Bandura, A. (1997). Self-efficacy: The exercise of control. New York: Worth Publishers.

Benson, P. (2001). Teaching and researching autonomy in language learning. London: Longman.

Benson, P. (2011). Teaching and Researching Autonomy (2nd ed.). London, UK: Taylor \& Francis.

Bernat, E., \& Gvozdenko, M. (2005). Beliefs about language learning: Current knowledge, pedagogical implications and new research directions. TESLJ-EJ, 9(1).

Bernhardt, S. (1997). Self-efficacy and L2 learning. The NCLRC Language Resource, 1(5).

Bobkina, J., \& Fernandez, M. (2012). Motivation and Attitudes towards Learning English: A Study of 
Engineering Undergraduates at the Technical University of Madrid. ICERI2012 Proceedings, 4492-4501.

Boonrangsri, K., Chuaymankhong, D., Rermyindee, N., \& Vongchittpinyo, N. (2004). The Attitude towards English Language Learning of the Students in Vocational Certificate Level under Curriculum in 2002. Thailand: A Case Study of Ayutthaya Technical College studied by Naresuan University.

Brown, H. (2000). Principles of language learning and teaching (4th ed.). White Plains, NY: Addison Wesley Longman.

Brown, J. (2008). Student-centered Instruction: Involving Students in Their Own Education. Music Educators Journal, 95(4).

Chemers, M., Hu, L., \& Garcia, B. (2001). Academic self-efficacy and first year college student performance and adjustment. Journal of Educational Psychology, 93(1), 55-64.

Collins, J., \& O’Brien, N. (2003). Greenwood Dictionary of Education. Westport, CT: Greenwood.

Cook, V. (2001). Second language learning and language teaching. London: Edward Arnold.

Cooper, J., MacGregor, J., Smith, K., \& Robinson, P. (2000). Implementing small-group instruction: Insights from successful practitioners. New Directions in Teaching and Learning, 81, 64-76.

Cotterall, S. (1995). Readiness for autonomy: Investigating learner beliefs, System, 23(2), 195-205.

Cotterall, S. (1999). Key variables in language learning: What do learners believe about them? System, 27, 493-513.

Dafei, D. (2007). An exploration of the relationship between learner autonomy and English proficiency. Asian EFL, Professional Teaching Articles.

Dam, L. (2011). Developing learner autonomy with school kids: principles, practices, results. In D. Gardner (Ed.), Fostering autonomy in language learning (pp. 40-51). Gaziantep: Zirve University.

DeBot, K., Lowie, W., \& Verspoor, M. (2005). Second language acquisition: An advanced resource book. London: Routledge.

Deci, E., \& Ryan, R. (1985). Intrinsic motivation and self-determination in human behavior. New York: Plenum Press.

Dias, R. (2000). Lebanese students' beliefs about learning English and French: A study of university students in a multilingual context. Dissertation Abstracts International, 62 (02), 497A (UMI No. 3004253).

Doordinejad, F., \& Afshar, H. (2014). On the relationship between self-efficacy and English achievement among Iranian third grade high school students. International Journal of Language Learning and Applied Linguistics World, 6(4), 461-470.

Dörnyei, Z. (1990). Conceptualizing motivation in foreign-language learning. Language Learning, 40(1), 45-78.

Dörnyei, Z. (1994). Motivation and motivating in the foreign language classroom. Modern Language Journal, 78, 273-284.

Dörnyei, Z. (1998). Motivation in second and FL learning. Language Teaching, 31(3), 117-135.

Dörnyei, Z. (2001). Teaching and researching motivation. Harlow, England, United Kingdom: Longman.

Dörnyei, Z. (2005). The psychology of language learner: Individual differences in second language acquisition. Mahvah, NJ: Lawrence Erlbaum.

DuckWorth, E. (2009). Helping Students Get to Where Ideas Can Find Them. The New Educators, 5, 185-188.

Ehrman, M., Leaver, B., \& Oxford, R. (2003). A brief overview of individual differences in second language learning. System, 31, 313-330.

Elkhafaifi, H. (2005). Listening comprehension and anxiety in the Arabic language classroom. The Modern Language Journal, 89(2), 206-220.

Fareh, S. (2010). Challenges of teaching English in the Arab world: Why can't EFL programs deliver as expected? Procedia Social and Behavioral Sciences, 2(2), 3600-3604.

Frugé, C. (2007). Epistemological congruency in community college classrooms: Effects of epistemological beliefs on students" experiences. Doctoral dissertation. Louisiana State University and Agricultural and Mechanical College. (ERIC Document Reproduction Service No. EJ794367).

Gaoyin, Q., \& Alvermann, D. (1995). Role of epistemological beliefs and learned helplessness in secondary 
school students' learning science concepts from text. Journal of Educational Psychology, 87(2), 282-292.

Gardner, R. C. (1985). Social psychology and second language learning: The role of attitudes and motivation. London: Edward Arnold.

Gardner, R. (1988). The socio-educational model of second language learning: Assumptions, findings, and issues. Language Learning, 38, 101-126.

Gardner, R. (2001). Integrative motivation and second language acquisition. In Z. Dörnyei, \& R. Schmidt (Eds.), Motivation and second language acquisition (pp. 19). Honolulu, HI: The University of Hawaii, Second Language Teaching \& Curriculum Center.

Gardner, R. C. (2010). Motivation and Second Language Acquisition: The Socio-Educational Model. New York: Peter Lang.

Gardner, R., \& Lambert, W. (1972). Attitudes and motivation in second-language learning. Rowley, MA: Newbury House.

Gardner, R., \& MacIntyre, P. (1991). An Instrumental Motivation in Language Study: Who says it isn't Effective? Studies in Second Language Acquisition, 13, 57-72.

Gardner, R. (1980). On the Validity of Affective Variables in Second Language Acquisition: Conceptual, Contextual, and Statistical Considerations. Language Learning, 30, 255-270.

Gass, S., \& Selinker, L. (2001). Second language acquisition: An introductory course. Mahwah, NJ: Erlbaum.

Geisli, Y. (2009). The effect of student centered instructional approaches on student success. Procedia Social and Behavioral Sciences, 1(1), 469-473.

Goktepe, F. (2014). Attitudes and motivation of Turkish undergraduate EFL students towards learning English language. Studies in English Language Teaching, 2(3).

Gravoso, R., \& Pasa, A. (2008). Design and Use of Instructional Materials for Student-Centered Learning: A Case in Learning Ecological Concepts. The Asia-Pacific Education Researcher, 17(1), 109-120.

Henk, W., \& Melnick, S. (1995). The reader self-perception scale (RSPS): A new tool for measuring how children feel about themselves as readers. The Reading Teacher, 48, 470-482.

Holec, H. (1981). Autonomy and Foreign Language Learning. Oxford, UK: Pergamon.

Horwitz, E. (1987). Surveying student beliefs about language learning. In A. Wenden, \& J. Rubin (Eds.), Learner strategies in language learning (pp. 119-129). Englewood, NJ: Prentice-Hall.

Horwitz, E. (1988). The beliefs about language learning of beginning university foreign language students. The Modern Language Journal, 72(3), 283-294.

Horwitz, E. (1989). Recent research on SL learners: Beliefs and anxiety. In D. A. Koike, \& A. R. M. Simoes (Eds.), Negotiating for meaning: Papers on foreign language teaching and testing (pp. 51-60). Texas Papers in Foreign Language Education, Special Edition.

Horwitz, E. (2001). Language anxiety and achievement. Annual review of applied linguistics, 21(1), 112-126.

Horwitz, E., Horwitz, M., \& Cope, J. (1986). Foreign language classroom anxiety. The Modern Language Journal, 70(2), 125-132.

Huba, M., \& Freed, J. (2000). Learner-Centered Assessment on College Campuses: Shifting the Focus from Teaching to Learning. Needham Heights, MA: Allyn \& Bacon.

Kassem, H. (2013). English as a Foreign Language Learning Beliefs and Attitudes of Saudi College English and Non-English Majors. Arab World English Journal, 4(4), 400-419.

Kern, R. (1995). Students' and teachers' beliefs about language learning. Foreign Language Annals, 28(1), $71-92$.

Khan, I. (2011). Learning difficulties in English: Diagnosis and pedagogy in Saudi Arabia. Educational Research, 2(7), 1248-1257.

Kiptui, D., \& Mbugua, Z. (2009). Factors that contribute to poor academic achievement in English in Kerio Valley schools. Kenya Journal of Educational Management, 1, 1-155.

Kroll, J., \& De Groot, A. (2005). Handbook of Bilingualism. Oxford: OUP.

Lak, M., Soleimani, H., \& Parvaneh, F. (2017). The Effect of Teacher-Centeredness Method vs. 
Learner-Centeredness Method on Reading Comprehension among Iranian EFL Learners. Journal of Advances in English Language Teaching, 5(1), 1-10.

Lewis, M., \& Reinders, H. (2008). Using student-centered methods with teacher-centered students. Ontario: Pippin Publishing.

Li, Y., \& Wang, C. (2010). An empirical study of reading self-efficacy and the use of reading strategies in the Chinese EFL context. Asian EFL Journal, 12(2), 144-162.

Little, D. (1991). Autonomy: Definitions, Issues and Problems. Dublin: Authentik.

Little, D. (2003). Learner Autonomy and Second/foreign Language Learning. Guide to Good Practice. Retrieved from https://www.llas.ac.uk/resources/gpg/1409

Little, D. (2009). Language learner autonomy and the European Language Portfolio: Two L2 English examples. Language Teaching, 42(2), 222-233.

Littlewood, W. (1996). Autonomy: An anatomy and a framework. System, 24(4), 427- 435.

Lynch, D. (2010). Student-Centered Learning: The Approach That Better Benefits Students. Virginia Wesleyaan Collage.

MacIntyre, P. (1995). How does anxiety affect second language learning? A reply to Sparks and Ganschow. The Modern Language Journal, 79(1), 90-99.

MacIntyre, P. \& Gardner, R. (1989). Anxiety and second language learning: Toward a theoretical clarification. Language Learning, 39(2), 251-75.

Mantle-Bromley, C. (1995). Positive attitudes and realistic beliefs: Links to proficiency. The Modern Language Journal, 79(3), 372-386.

Masny, D., \& Foxall, J. (1992). Writing apprehension in L2. ERIC Document, No. ED 352844.

McCombs, B., \& Whistler, J. (1997). The Learner-Centered Classroom and School. Strategies for Increasing Student Motivation and Achievement. Sam Francisco: Jossey Bass Publishers.

Mermelstein, A. (2015). Asian EFL university students' preference toward teaching approaches. The CATESOL Journal, 27(2), 259-279.

Mills, N., Pajares, F. \& Herron, C. (2007). Self-efficacy of college intermediate French students: Relation to achievement and motivation. Language Learning, 57(3), 417-442.

Mohammed, A. (2015). EFL effective factors: Anxiety and motivation and their effect on Saudi college students' achievement. Arab World English Journal, 6(2), 201-218.

Moskovsky, C., \& Alrabai, F. (2009). Intrinsic Motivation in Saudi Learners of English as a Foreign Language. The Open Applied Linguistics Journal, 2, 1-10.

Noels, K., Pelletier, L., Clément, R., \& Vallerand, R. (2000). Why are you learning a second language? Motivational orientations and self-determination theory. Language Learning, 50, 57-85.

Nunan, D. (1997). Designing and adapting materials to encourage learner autonomy. In P. Benson, \& P. Voller (Eds.), Autonomy and independence in language learning (pp. 192-203). New York: Longman.

Oh, M-J. (1996). Beliefs about language learning and foreign language anxiety: A study of American university students learning Japanese. Dissertation Abstracts International, 57(09), 3858A. (UMI No. 9705927).

Oxford, R. (1996). Language Learning Motivation: Pathways to the New Century. Honolulu: University of Hawaii Press.

Oxford, R., \& Shearin, J. (1994). Language learning motivation: Expanding the theoretical framework. The Modern Language Journal, 78(1), 12-28.

Oxford, R. (1999). Anxiety and language learner: new insights. In J. Arnold (Ed.), Affect in Language Learning (pp. 260-278). Cambridge, UK: Cambridge University Press.

Oxford, R. (1990). Language learning strategies: what every teacher should know. Rowley, MA: Newbury House.

Öz, H. (2007). Understanding metacognitive knowledge of Turkish EFL students in secondary education. Novitas-Royal, 1(2), 53-83.

Pajares, F. (1996). Self-efficacy beliefs in academic settings. Review of Educational Research, 66, 543-578. 
Peacock, M. (1997). The effect of authentic materials on the motivation of EFL learners. English Language Teaching, 51(2), 144-156.

Peyton, J., More, S. \& Young, S. (2010). Evidence-based, Student-centered Instructional Practices. Center for Applied Linguistic. Retrieved August, 2018, from https://files.eric.ed.gov/fulltext/ED540599.pdf

Pintrich, P., \& Schunk, D. (2002). Motivation in education: Theory, research, and application (2nd Ed.). Upper Saddle River, NJ: Merrill Prentice Hall.

Rahemi, J. (2007). Self-efficacy in English and Iranian senior high school students majoring in Humanities. Novitas-Royal, 1(2), 98-111.

Rahimi, A., \& Abedini, A. (2009). The interface between EFL learners' self-efficacy concerning listening comprehension and listening proficiency. Novitas Royal, 3(1), 14-28.

Rajab, H. (2013). Developing speaking and writing skills of L1 Arabic EFL learners through teaching of IPA phonetic codes. Theory and Practice in Language Studies, 3, 653-659.

Reece, I. \& Walker, S. (1997). Teaching, Training and Learning. A Practical Guide (3rd ed.). Great Britain: Business Education Publishers Limited.

Reinders, H. (2010). Towards a classroom pedagogy for learner autonomy: A framework of independent language learning skills. Australian Journal of Teacher Education, 35(5), 40-55.

Richards, J., \& Schmidt, R. (2002). Longman Dictionary of Language and Applied Linguistics. London: Longman.

Richards, J., \& Schmidt, R. (2010). Longman dictionary of language teaching and applied linguistics (4th ed.). London: Longman.

Saka, S., \& Takagi, A. (2009). Relationship between Learner Autonomy and English Language Proficiency of Japanese Learner. The Journal of Asia TEFL, 6(3), 297-325.

Schmidt, R., Boraie, D., \& Kassabgy, O. (1996). Foreign language motivation: Internal structure and external connections. In R. Oxford (Ed.), Language learning motivation: Pathways to the new century (pp. 9-70). Honolulu: University of Hawai'i Press.

Schumann, J. (1998). The Neurobiology of Affect in Language. Language Learning, 48(Supplement 1).

Schunk, D. (2003). Self-Efficacy for Reading and Writing: Influence of Modeling, Goal Setting, and Self-Evaluation. Reading and Writing Quarterly, 19, 159-172.

Schunk, H., \& Pajares, F. (2005). Competence perceptions and academic functioning. In A. J. Elliot, \& C. S. Dweck (Eds.), Handbook of Competence and Motivation (pp. 85-104). New York: Guilford Press.

Seeger, V. (2009). Collaborative retrospective miscue analysis: A pathway to self-efficacy in reading. Ph.D. Dissertation, Kansas State University, Manhattan, Kansas.

Sellers, V. (2000). Anxiety and reading comprehension in Spanish as a foreign language. Foreign Language Annals, 33, 512-521.

Sinclair, B. (2000). Learner autonomy: The next phase. In B. Sinclair, I. McGrath, \& T. Lamb (Eds.), Learner autonomy, teacher autonomy: Future directions (pp. 4-14). Essex: Pearson Education Ltd.

Slavin, R. (2003). Educational psychology: Theory and practice (7th ed.). Boston, MA: Allyn and Bacon.

Tahaineh, Y., \& Daana, H. (2013) Jordanian Undergraduates' Motivations and Attitudes towards Learning English in EFL Context. International Review of Social Sciences and Humanities, 4(2), 159-180.

Tilfarlioğlu, F., \& Cġnkara, E. (2009). Self- Efficacy in EFL: Differences among proficiency groups and relationship with success. Novitas-ROYAL, 3(2), 129-142.

Truitt, S. (1995). Anxiety and beliefs about language learning: A study of Korean university students learning English. Dissertation Abstracts International, 56(06), 2155A. (UMI No. 9534977)

Mori, Y. (1999). Epistemological beliefs and language learning beliefs: What do language learners believe about their learning? Language Learning, 49, 377-415.

Vallerand, R., Pelletier, L., Blais, R., Briere, N., Senecal, C., \& Vallieres, E. (1992). The Academic Motivation Scale: A measure of intrinsic, extrinsic, and amotivation in education. Educational and Psychological Measurement, 52, 1003-1017. 
Vallerand, R., Pelletier, L., Blais, R., Briere, N., Senecal, C., \& Vallieres, E. (1993). On the assessment of intrinsic, extrinsic and amotivation in education: Evidence on the concurrent and construct validity of the Academic Motivation Scale. Educational and Psychological Measurement, 53, 159-172.

Visser, M. (2008). Learning under conditions of hierarchy and discipline: The case of the German Army (1939-1940). Learning Inquiry, 2, 127-137.

Wenden, A. (1991). Learner Strategies for Learner Autonomy. London: Prentice Hall.

Wenden, A. (1999). Commentary: An introduction to metacognitive knowledge and beliefs in language learning: beyond the basics. System, 27(4), 435-441.

Wigfield, A., \& Guthrie, J. (1997). Relations of children's motivation for reading to the amount and breadth of their reading. Journal of Educational Psychology, 89(3), 420-432.

Wong, Y. (2011). A study of instrumental and integrative motivations as factors influencing UTAR third year Chinese undergraduates in learning ESL. Doctoral dissertation, UniversitiTunku Abdul Rahman.

Yashima, T. (2002). Willingness to communicate in a second language: The Japanese context. The Modern Language Journal, 86(1), 54-66.

Young, D. (1991). Creating a low anxiety classroom environment: What does language anxiety research suggest? The Modern language journal, 75(4), 426-439.

\section{Appendix}

\section{The Questionnaire}

\begin{tabular}{ll}
\hline No. & Statement \\
\hline & Anxiety \\
1 & I never feel quite sure of myself when I am speaking in English. \\
2 & I don't worry about making mistakes in language class. \\
3 & I tremble when I know that I'm going to be called on in language class. \\
4 & During language class, I find myself thinking about things that have nothing to do with the course. \\
5 & I start to panic when I have to speak without preparation in language class. \\
6 & In English classes, I can get so nervous I forget things I know. \\
7 & It embarrasses me to volunteer answers in my language class. \\
8 & I would not be nervous speaking the foreign language with native speakers. \\
9 & I can feel my heart pounding when I'm going to be called on in language class. \\
10 & I feel very self-conscious about speaking the foreign language in front of other students. \\
11 & I am afraid that the other students will laugh at me when I speak the foreign language. \\
12 & I get nervous when the English teacher asks questions which I haven't prepared in advance. \\
\hline
\end{tabular}

\section{Motivation}

13 I study English because it will be helpful for my future career.

14 Studying English gives me pleasure.

15 I study English to get a good job.

16 I study English because I'm interested in English culture, history or literature.

17 I study English because people respect persons who know English.

18 Studying English will help me to understand English speaking people and their way of life.

19 Knowing English gives me a feeling of success.

20 I study English for the good feeling I have when I use it to express myself and understands things.

21 Studying English is important to me because without it one cannot be successful in any field.

22 I study English, so I communicate with foreign people. 


\section{Attitude}

23 I wish I could have many English speaking friends.

24 I like my English class so much; I look forward to studying more English in the future.

25 Frankly, I study English just to pass the exams.

26 In my opinion, people who speak more than one language are distinguished.

27 Studying English makes me proud.

28 I feel excited when I communicate in English with others.

29 Studying English is enjoyable.

30 Studying English makes me have good feelings.

31 I enjoy doing activities in English inside and outside the classroom.

32 I do not like studying English.

33 I wish I could speak English fluently.

34 I am interested in studying English.

35 Knowing English is an important goal in my life.

36 I look forward to the time I spend in English classes.

\section{Autonomy}

37 I make good use of my free time in English study.

38 It is important to me to see the progress I make.

39 I attend out-class activities to practice and learn English.

40 I know my strengths and weaknesses in my English study.

41 I can set goals for my English study.

42 I have my own ways of testing how much I have learned.

43 I know how my language learning progresses.

44 I can work well on my weaknesses in my English study.

45 I know how to study English well.

46 I know how to check my works for mistakes.

47 I organize and allocate time well when I study English.

48 My success in learning English mainly depends on my own efforts.

49 I'm good at using resources like the Internet and the library for my English study.

50 I like to talk to the teacher about the quality of my work and assignments.

51 I keep a notebook where I jot down English vocabulary and important information.

52 I can make use of English movies to promote my English proficiency.

53 After a test I always review difficult material to be sure I understand it all.

54 When I use the Internet or the library, I know how to select material that suits my purposes.

55 The English teacher is completely responsible for my learning.

56 It is up to the language learner to find opportunities to practice the foreign language.

57 Language learners are responsible for planning for their own learning.

58 The role of the English teacher is to help me learn by myself.

\section{Self-efficacy}

59 I have a special ability for learning English.

60 I believe that I will ultimately learn to speak English very well

61 I'm satisfied with my current level of English proficiency. 
62 I'm sure that I can improve my English.

63 I can say that my confidence in English classes is high.

64 I am not good at solving the problems I face in learning English.

65 I get upset when I take an English exam.

66 I always think that other students are better learners of English than I am.

67 I know how to improve my English

68 In general, I am a good language learner.

69 Before I start a task in my English class, I don't think that I can do it well.

70 When I find a task/assignment difficult, I usually give up.

71 I feel calm when I participate in group or whole-class activities.

72 I think that achieving good language proficiency is easy.

73 I can identify and overcome my weaknesses in English

74 I can concentrate more in English classes than I could before.

75 When I encounter difficulties in learning English, I do not give up

76 I think I learn English well compared with my classmates

77 I'm less confident in language learning than other students are.

78 I do not think that I am a good learner of English

\section{Belief about Language Learning}

79 Learning English should be limited to persons who need it.

80 A poor learner of English will remain so throughout years of study.

81 Everyone can learn to speak English

82 English is a very difficult language.

83 Success in learning English depends on the teacher, not on the student.

84 You should not say anything in English until you can say it correctly.

85 Making mistakes is a natural part of language learning.

86 Learners should speak English even if they would make mistakes.

87 The main role of the English teacher is to create activities and opportunities for learning and practice.

\section{Copyrights}

Copyright for this article is retained by the author(s), with first publication rights granted to the journal.

This is an open-access article distributed under the terms and conditions of the Creative Commons Attribution license (http://creativecommons.org/licenses/by/4.0/). 